Sains Malaysiana 49(9)(2020): 2091-2099

http://dx.doi.org/10.17576/jsm-2020-4909-07

\title{
Nocturnal Blue Light Exposure Increase Alpha and Beta Brain Waves as Cognition Function for Two Consecutive Night Driving in a Car Simulator
}

(Pendedahan Cahaya Biru Nokturnal Meningkatkan Gelombang Otak Alfa dan Beta sebagai Fungsi Pengecaman untuk Dua Pemanduan Malam Berturut-turut dalam Pensimulasi Kereta)

\section{Lulu Lusianti Fitri*, KinANTi Prestiasani \& Suprijanto}

\begin{abstract}
Driving is a complex activity that engage complex motor, sensor, and cognitive function which can be analyzed through brain wave using electroencephalograph (EEG). Decrease of cognitive function while driving in long period at night linked with drowsiness and exposure of blue light to driver in night-driving could improve cognitive function; yet, studies describing its exposure in longer duration and repetition effects are needed. In this study, 15 adult males experienced driving session on the car simulator with a straight and monotonous road for 2 consecutive nights for 30 min without pause. The participants were divided into three driving groups as follows: in dark condition (control), under exposure to polychromatic blue light (450-540 nm) and monochromatic blue LED light (460 nm). All participants'brain waves were recorded by EEG during the driving session from two channels of $F 3$ and $F 4$ representing cognitive function of the brain. The result showed that there was a significant increase of beta and alpha wave power spectral density on the second day of exposure in both blue light treatment groups. However, monochromatic blue light gave a more stable beta wave than the other two lights which incidate a much stronger cognitive process. There was also a synchronization from both channels of F3 and F4 in all treatments which shows that aplha and beta wave do not necessarily work in an antagonistic way. In summary, repeated, continuous exposure of blue light may increase aplha and beta wave power spectral density, in which monochomatic blue light cuses better cognitive state than polychromatic blue light.
\end{abstract}

Keywords: Blue light; brain wave; driving simulator; EEG; power spectral density

ABSTRAK

Memandu ialah aktiviti kompleks yang dipengaruhi fungsi motor, sensor dan pengecaman otak serta dapat diukur melalui perangkat elektroensefalograf (EEG). Memandu pada tempoh yang lama pada waktu malam boleh meningkatkan rasa mengantuk serta menurunkan fungsi pengecaman. Ini dapat dibantu dengan mendedahkan cahaya biru untuk meningkatkan fungsi pengecaman, namun data menunjukkan bahawa pendedahan memerlukan tempoh yang lama dan berulang. Kajian ini menggunakan 15 pemandu lelaki dalam pensimulasi kereta selama dua malam berturut-turut di jalan raya yang lurus dan bosan selama 30 min tanpa berhenti. Pemandu dibahagikan kepada tiga kumpulan iaitu: tanpa cahaya (kawalan), pendedahan kepada cahaya biru polikromatik (450-540 nm) dan pendedahan cahaya biru LED monokromatik (460 nm). Gelombang otak setiap pemandu diukur menggunakan EEG daripada dua saluran F3 dan F4 yang mewakili fungsi pengecaman di otak, Hasil menunjukkan kenaikan daya gelombang beta dan alfa secara bererti $(p<0.01)$ pada hari kedua dalam kedua-dua pendedahan cahaya biru. Gelombang beta cahaya biru monokromatik lebih stabil sejurus menjelaskan berlangsungnya proses pengecaman yang lebih tinggi berbanding cahaya biru polikromatik dan kawalan. Penyegerakan pola gelombang otak di F3 dan F4 menunjukkan gelombang alfa dan beta tidak perlu bertindak secara bertentangan. Secara rumusan, pendedahan berulang cahaya biru dapat meningkatkan gelombang alfa dan beta pada fungsi pengecaman otak ketika memandu pada waktu malam dan cahaya biru monokromatik memfasilitasi proses pengecaman yang lebih baik daripada cahaya biru polikromatik.

Kata kunci: Cahaya biru; EEG; gelombang otak; nilai daya gelombang; pensimulasi memandu

\section{INTRODUCTION}

Organisms always interact with their environment, as its condition affects both physiological and behaviour, especially for human. Indonesia, an archipelago country close to Malaysia, is located in the equator line with the yearly sun lighting up to 60.000-80.000 Lux (Zain-Ahmed et al. 2002) and solar irradiation ranging between 4.6-7.2 $\mathrm{kWh} / \mathrm{m}^{2}$ (Rumbayan et al. 2012). This condition shapes the 
people who live in Indonesia and other tropical countries to get used to fairly high annual light intensity. Moreover, the equatorial location also implies that the duration of night and day throughout the year affects the people's circadian rhythm (Küller 2002).

The sun is a polichromatic light and it consists of more than one wavelength (Treutlein 2016), while visible light has wavelengths of 380-780 nm, which consists of various colors (Blume et al. 2019). These lights are responded by rod and cone cells in the eye's retina to be processed further as visual information in the brain, though there is one type of blue light spectrum process differently as non-visual information through specific receptor namely Intrinsically Photoreceptic Ganglion Cell (ipRGC) (Cao \& Barrionuevo 2015). The ipRGC is connected to the circadian rhythm and attention so its role is crucial in managing individual activities (Blume et al. 2019). At night when there is no natural lighting from the sun, humans apply artifical light at workplace or home, and LED light is used widely. Although artificial light such LED appears white, but LED still have peak emission of blue light ranging about 400-490 nm (Tosini et al. 2016). Based on data from the National Transportation Safety Committee, traffic accident occurred in Indonesia was caused by human factors about 69\% (KNKT 2016) and raised up to $72 \%$ in 2019 (Republika 2019). This human factor is due to drowsiness or distraction while driving and drowsiness alone contributed up to $30 \%$ of driving accident (Boyce et al. 2006). When driving during the day, ipRGC will give a signal to the brain to increase the hormone melatonin in the body and feeling drowsy. This causes a condition called driving drowsiness which is characterized by a decrease in cognitive function due to deficit in information processing and longer reaction time to respond in dangerous situation (Lin et al. 2005).

Since driving is a complex process involving planning and appropriate execution based on the comprehension of the surroundings, the brain's frontal lobe is important for executive functioning, including attention, wakefulness, working memory process, and decision making (Sakai et al 2012). A study using hemoglobin density as measured by NIRS (Near Infrared Spectroscopy) has shown changes in frontal lobe when participants were actively moving their hand while driving indicate highly activity in the brain region (Takahashi et al. 2011). Things done to the brain occur in the cerebral cortex can be measured using electroencephalograph (EEG) device. This tool measures the electrical activity of the brain that can represent the state of the human brain in real-time (Subha et al. 2010). However, when drowsiness occurs during night driving, it is manifested as a decrease, intermittent and decline of alpha brain wave, followed by a low-voltage, combined pattern and height waves in EEG data (Santamaria \& Chiappa 1987). In an attempt to reduce drowsiness, blue light has been applied in an experiment at night to participants driving in simulator and shown their beta brain waves increased when compared to the dark condition (Fitri et al. 2018). In a similar study, participant drove in the simulator for $16 \mathrm{~min}$, consisted of $8 \mathrm{~min}$ adaptation and $8 \mathrm{~min}$ of driving taken for 2 nights consecutively, either in blue light irradiation or in darkness, showed that beta waves in every 2 min pattern in several cortex areas such as in frontal, parietal, premotor cortex, and visual (Purawijaya et al. 2015). In this research, the purpose of this study was to analyze the effect of monochromatic blue light or polychromatic LED light exposure on alpha and beta brain waves as measured by EEG, the influence of light exposure within $30 \mathrm{~min}$ duration and repeated driving affect the performance in driving simulator.

\section{MATERIALS AND METHODS}

\section{INSTRUMENTS AND MATERIAL}

The instruments used in this experiment were Electroencephalograph (EEG) EMOTIV EPOC 3.0.0.41, a laptop, a simulator set consists of Logitech G27 steering wheel, and a 40 inch LED TV a steering chair. Two light stimuli were applied: a pair of Phillips GO LITE (460 nm monochromatic blue light) and a pair of white LED (450-540 nm polychromatic light) with layers of blue transparent coating the lamp were used as a placebo. The material used in this research was saline water as a conductor for the EEG electrodes. The spectral distributions of both LED arrays are assessed by the Engineering Physic Department, Faculty of Industrial Technology, Insitut Teknologi Bandung.

\section{TIME, PLACE, AND EXPERIMENT CONDITIONS}

This experiment was conducted at Medical Instrumentation Laboratory, Engineering Physics Department Institute Teknologi Bandung. The Installation of driving simulator on Figure 1 consists of LCD screen located $1.3 \mathrm{~m}$ from steering chair that equipped with steering wheel, and a set of clutch, brake and accelerator. In front of the steering chair, there were a set of blue light that positioned like on a car dashboard. These blue lights were connected with a system that allows the researcher to activate the light stimuli from distance. The software used in this experiment bas City Car Simulator 2.0 in the Free Driving night mode. The road used in the experiment also prepared as monotonous straight highway with no traffic activity on the road. Figure 2 represents the interface of the car simulator. To create the closest condition with real night time driving experience, the room has lighting and outside sound source minimalized. 


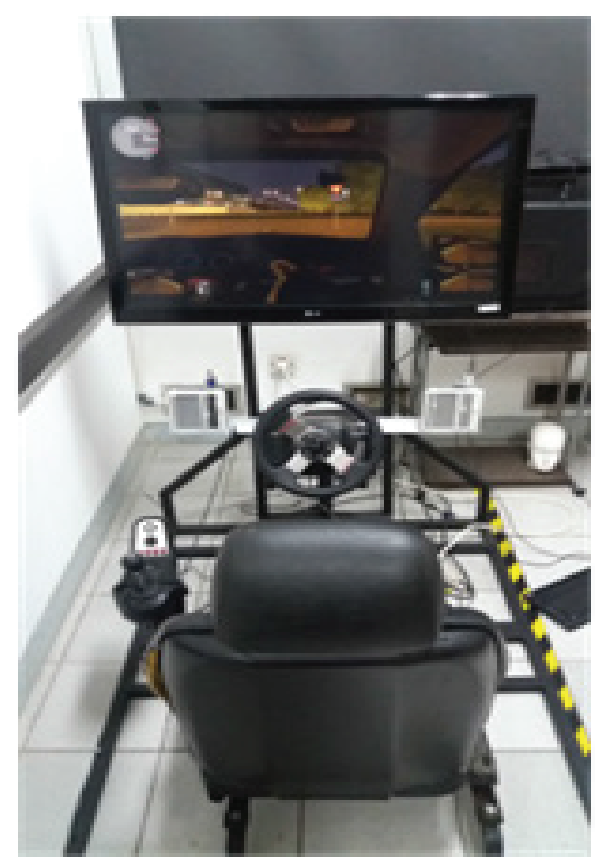

FIGURE 1. Simulator installation consists of driving simulator, LCD screen and a set blue lights on the dashboard

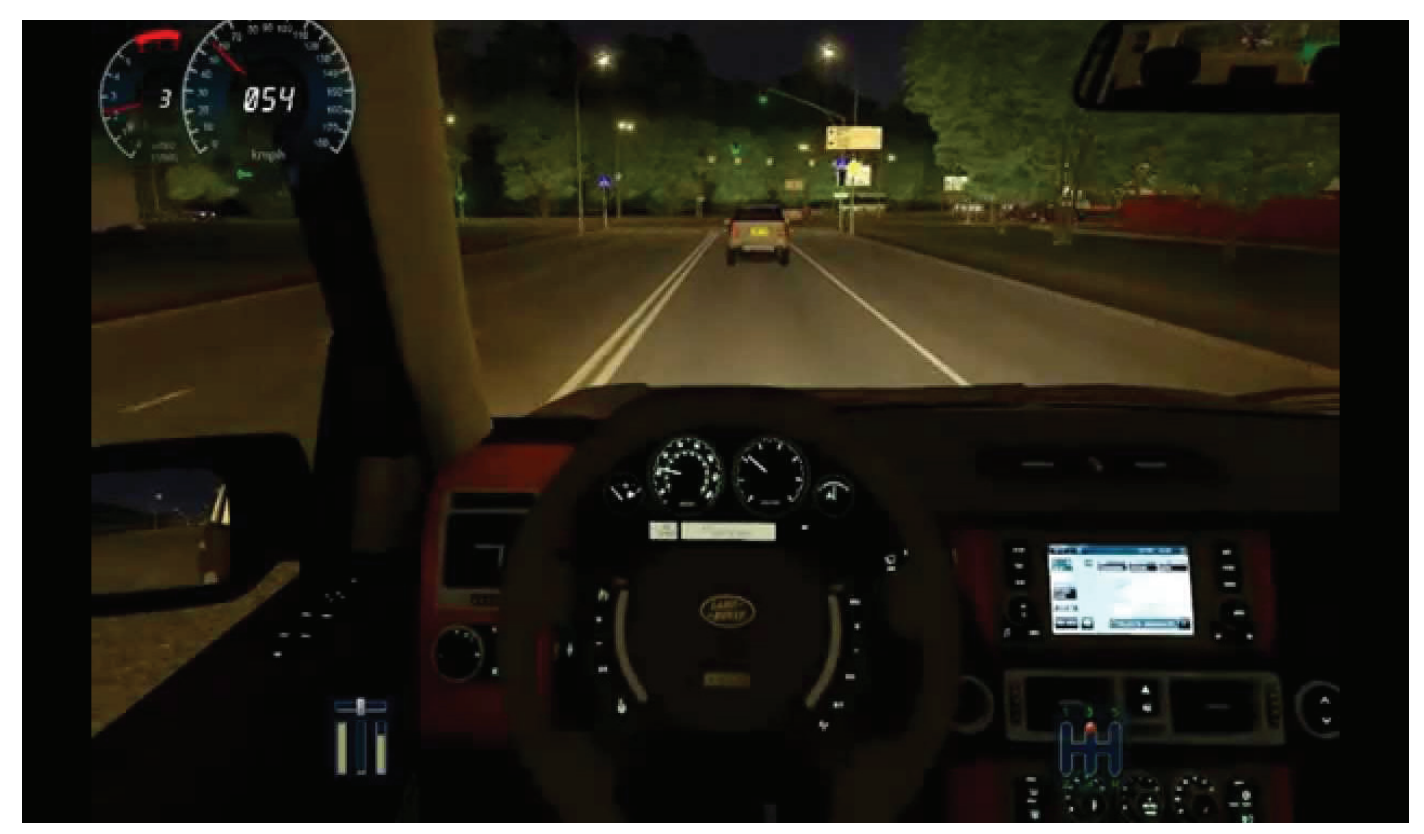

FIGURE 2. Interface of City Car Simulator with night mode and no traffic activity 


\section{DATA COLLECTING}

There are three sessions of the experiment: conditioning, habituation, and recording session. In conditioning session, the tools and materials needed were prepared and re-checked prior to the experiment. All 15 male participants were provided written informed consent prior engagement to the study. In the habituation session, the participants were allowed to make themselves familiar with the car simulator game set for 5-15 min. Next, the participant has EEG assembled into their head. In the recording session, the participant drove in the simulator for 30 min non-stop in a highway with speed range of 40-
$60 \mathrm{~km} / \mathrm{h}$. This speed range intended to minimize accident risk in the game during the recording session. Duration of the recording session is $30 \mathrm{~min}$, which consists of $2 \mathrm{~min}$ of baseline brainwave recording and $28 \mathrm{~min}$ of recording with lighting treatment. There are three group of light treatment in this experiment: control, with no additional light, polychromatic LED light as placebo blue light with wavelength of 450-540 nm, and monocrhomatic LED blue light with wavelength of $460 \mathrm{~nm}$. There are two areas of the brain that recorded using the EEG: the left and right side of the frontal lobe, namely F3 and F4. Table 1 explains the conditon of each treatment groups for a total of $30 \mathrm{~min}$ and Table 2 describes the research design.

TABLE 1. Scheme of EEG recordings

\begin{tabular}{|c|c|c|c|}
\hline Duration & Phase I 15 minutes & Phase II 120 seconds & Phase III 28 minutes \\
\hline Agenda & $\begin{array}{l}\text { Conditioning and } \\
\text { habituation on simulator }\end{array}$ & Baseline & $\begin{array}{l}\text { Driving in Highway without } \\
\text { distraction and obstacle }\end{array}$ \\
\hline Light & None & None & Darik/Blue Light (random) \\
\hline Treatment & - & - & $\begin{array}{l}\text { Group 1: Dark } \\
\text { Group 2: LED Blue Light Placebo } \\
\text { Group 3: LED Blue Light }\end{array}$ \\
\hline Note & No EEG recordings & EEG recordings & EEG recordings \\
\hline
\end{tabular}

TABLE 2. Research design

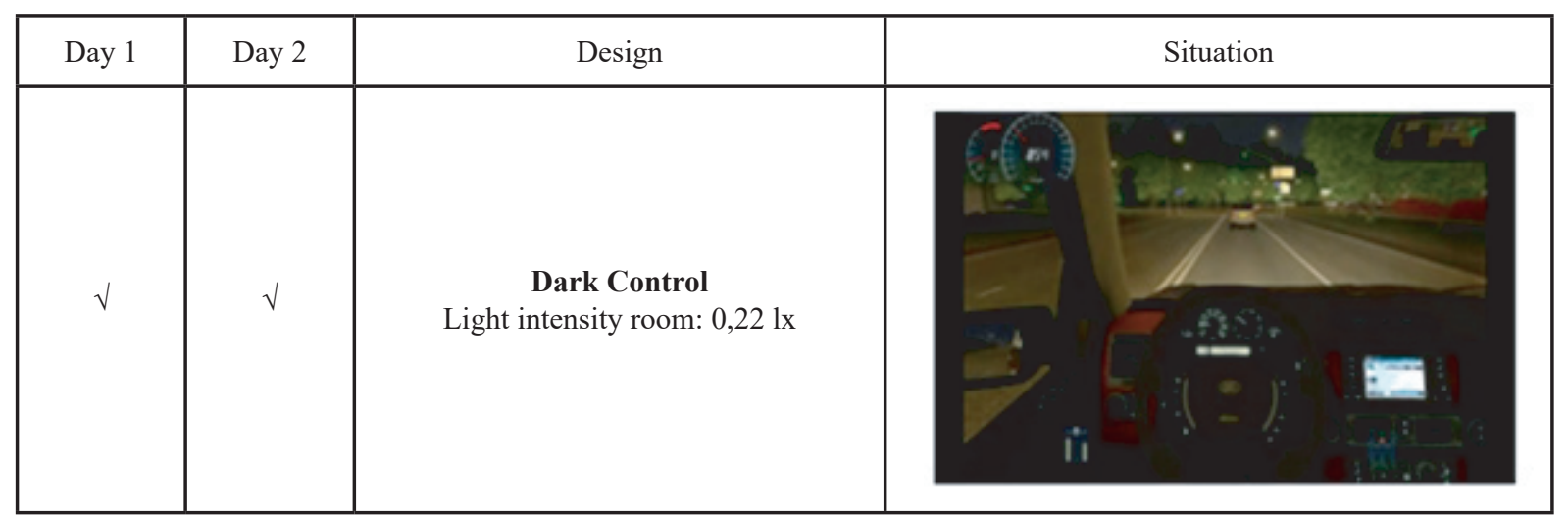




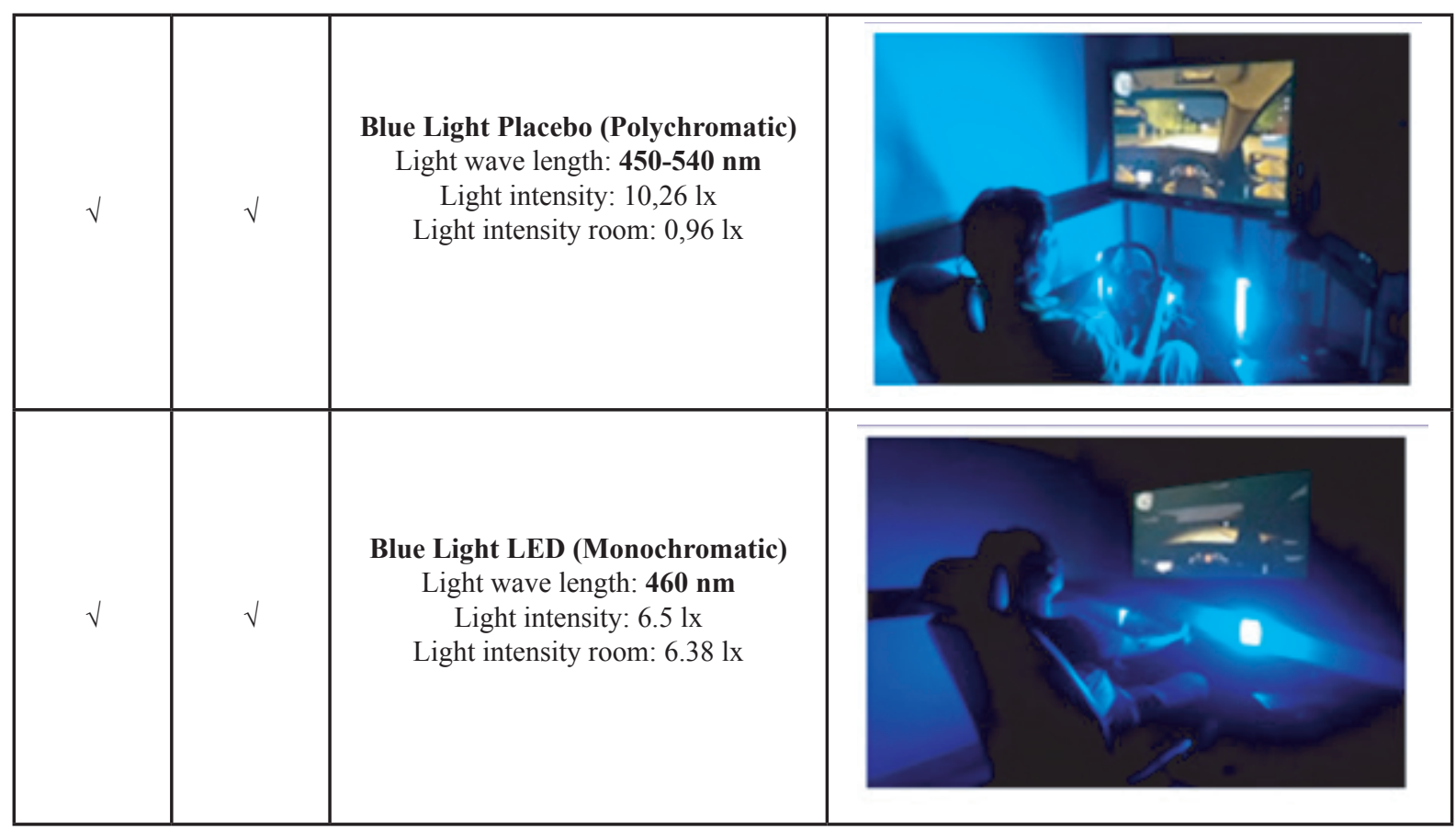

\section{DATA PROCESSING}

After the EEG recording session, the EEG data Wat extracted from .edf format to .csv format and then from the brain wave recording, the total wave data to be analyzed can be determined in number. Based on the $128 \mathrm{~Hz}$ sampling rate (128 data per s), three treatment groups, two points of the brain area observed, so that there are only 28 points from the total observation of $30 \mathrm{~min}$. Statistical analysis were done using the General Lineal Model with $95 \%$ of significant values.

\section{RESULTS AND DISCUSSION}

The measurement result of spectral distribution both LED light is seen in Figure 3. The Polychromatic LED light has wavelength 450-540 $\mathrm{nm}$ and Monochromatic LED light has wavelength $460 \mathrm{~nm}$. Based on the brain wave recordings, the total wave data to be analyzed was determined in number. Based on the $128 \mathrm{~Hz}$ sampling rate (128 data per s), three treatment groups, two points of the brain area observed, the duration of data retrieval was $1800 \mathrm{~s}$ and the number of data from 15 participants with each repetition twice, it can be determined that the total brain wave data what must be analyzed is $128 \times 3 \times 2 \times$ $1800 \times 30=41,472,000$. This data was then transformed from the time domain into the frequency domain using the Fast Fourier Transfer algorithm so that it could be presented in the form of a Power Spectral Density (PSD) graph represents the average value of a wave from a certain time span. In Figures 4 and 5, it can be seen that the PSD chart represents the value of power every minute of the observation session and does not include the baseline value so that there are only 28 points from the total observation of $30 \mathrm{~min}$.
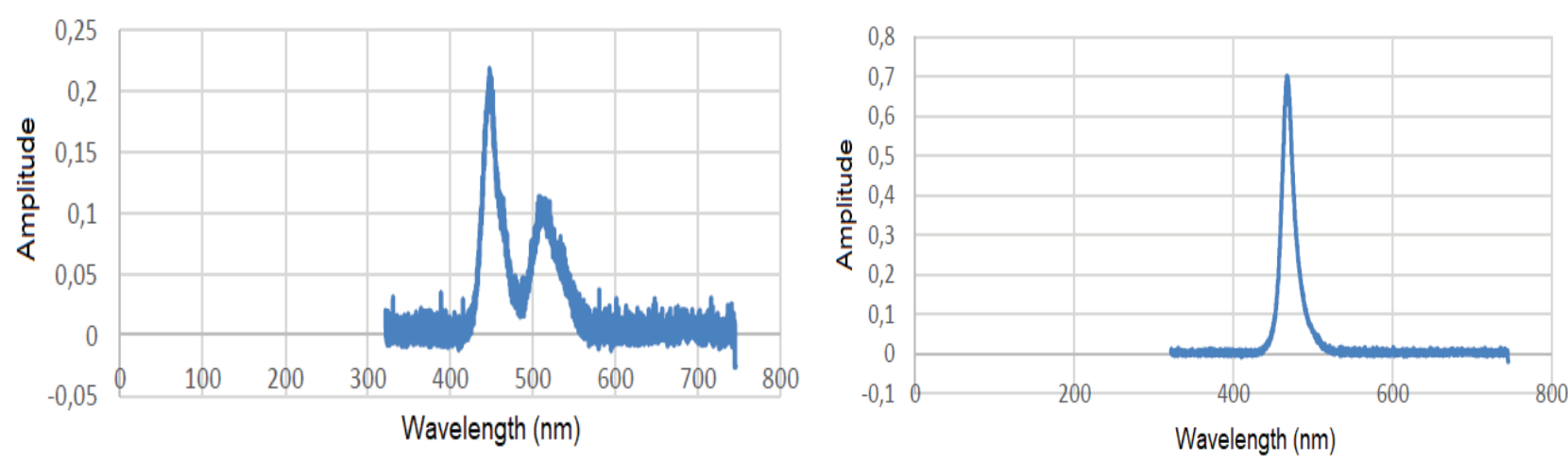

FIGURE 3. The spectral distribution of (a) Polychromatic LED light (wavelength 450-540 nm) and (b) monochromatic LED light (wavelength $460 \mathrm{~nm}$ ) 
PROFILE OF ALPHA AND BETA BRAIN WAVES IN ALL CONDITION

The power spectral graph contains data on the alpha brain waves in each treatment group, left (F3) and right (F4) lobes, on the first and second days of treatment in dark condition (Figures $4 \& 5$ ). In general, these are several phenomenon regarding the alpha and beta brain waves in all treatments as follows. In dark condition, alpha waves power tend to stabilize in dark condition, though alpha waves increased slightly but significantly $(\mathrm{p}<0.05)$ on the second day, while beta waves increased higher significantly $(\mathrm{p}<0.01)$ and more fluctuated compared with alpha brain waves. Under the placebo blue light (Polychromatic light) irradiation, both alpha and beta brain waves increased significantly higher in the second night $(p<0.01)$ and beta brain waves were more fluctuated than the alpha waves, particularly near the end of session. During exposure of monochromatic blue light, both alpha and beta brain waves were higher significantly $(\mathrm{p}<0.01)$ on the second night, compared to the first night. Moreover, beta brain waves were higher and more fluctuated in the first 4-6 min of the second night indicated higher function of cognitive activity. Above all, the right hemisphere (F4) showed significantly higher activity than the left hemisphere in all treatments indicating the right hemisphere was more dominant in cognitive function during driving at night.

(a) DARK, ALPHA

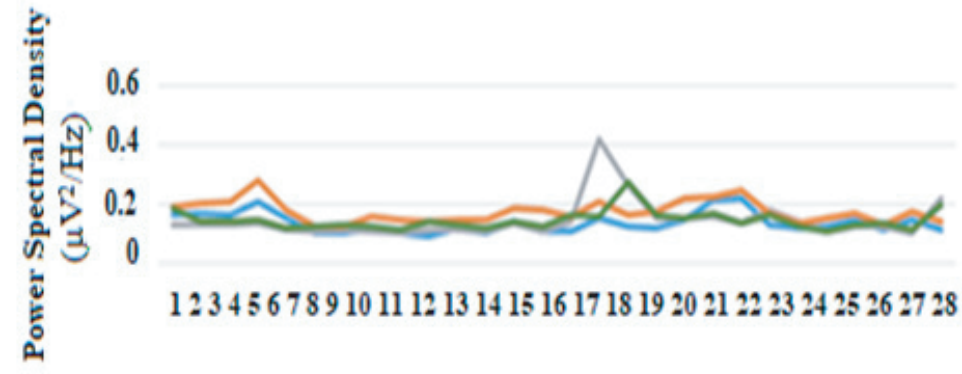

(b) PLACEBO, ALPHA

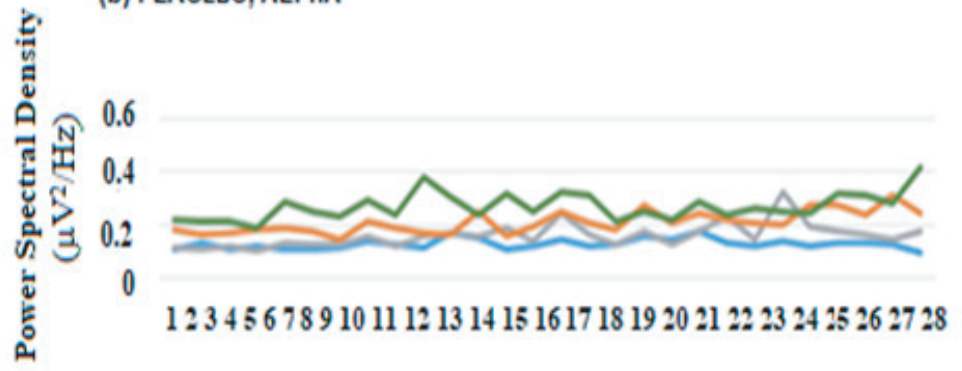

(c) BLUE LIGHT, ALPHA

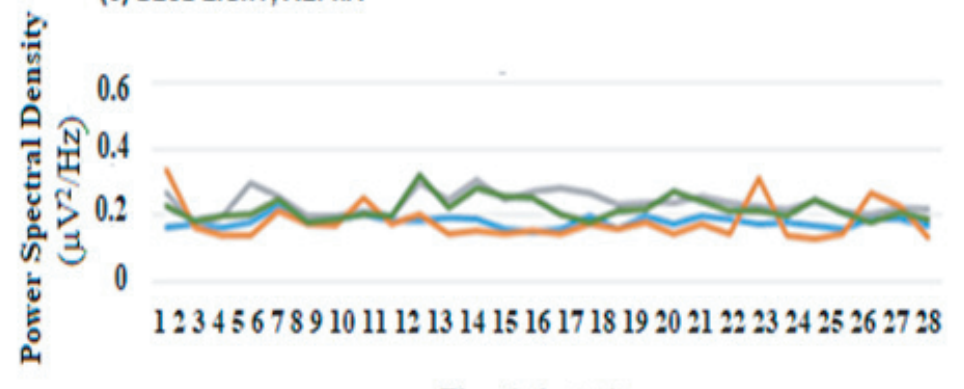

Time (minutes)

— Left, Dayl —Left, Day2 - Right, Dayl — Right, Day2

FIGURE 4. Power Spectral Density of alpha Brainwave on each treatment (a) dark, (b) blue light placebo (polychromatic light), and (c) blue light (monochromatic light), from the left (F3) and right (F4) of the frontal lobe 


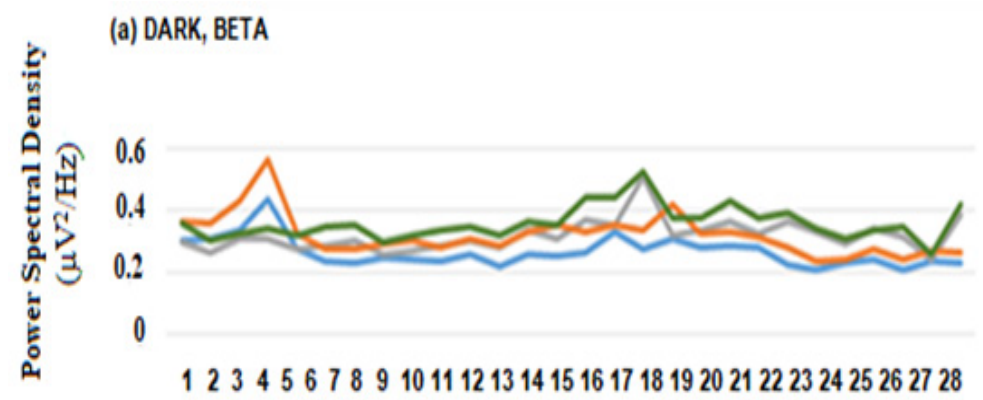

(b) PLACEBO, BETA
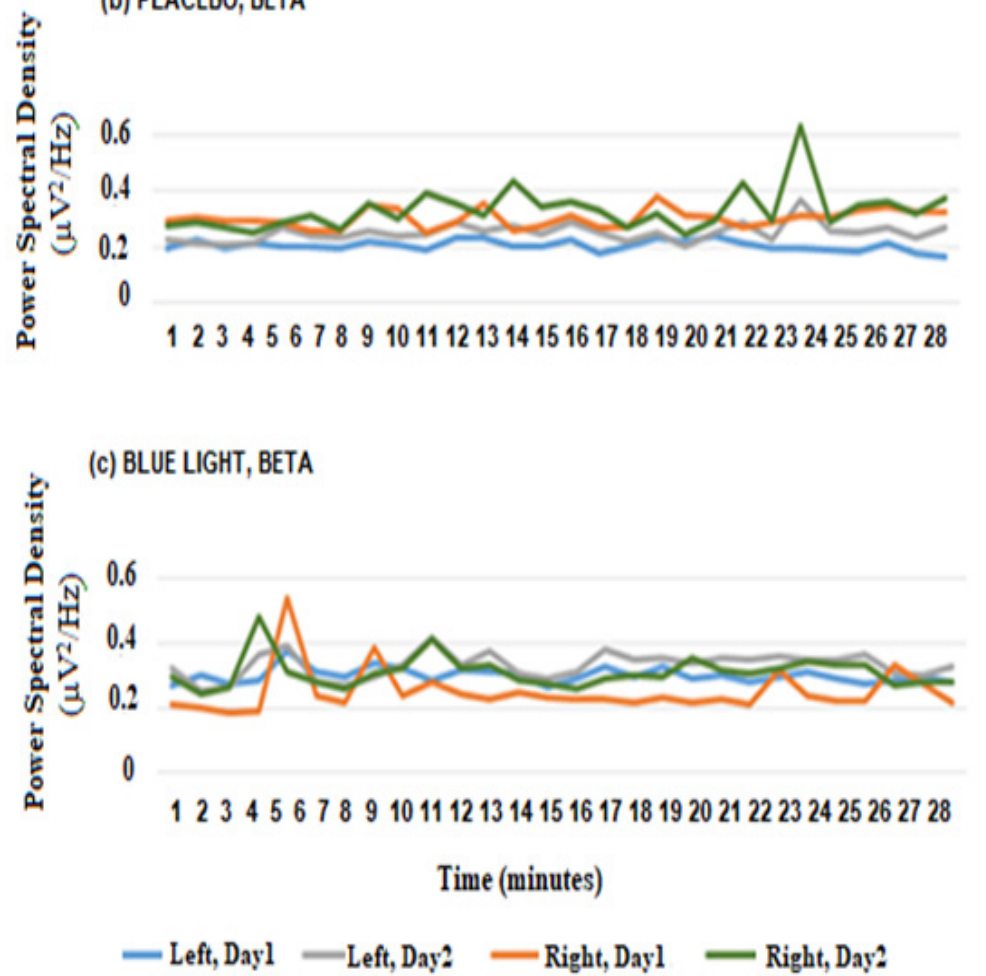

FIGURE 5. Power Spectral Density of alpha brainwave on each treatment (a) dark, (b) blue light placebo (polychromatic light), and (c) blue light (monochromatic light), from the left (F3) and right (F4) of the frontal lobe

The occurrence of alpha brain waves that stay stabilize in darkness suggests relaxed state, while beta brain waves were higher and fluctuated indicating that participants were still active in giving attention to drive. Thus, dynamic oscillation of beta brain waves in dark as well as in lighting condition showed the synchronization did not occur at all time, indicating that attention and focus arose intermittently and alternately with alpha waves (Lim et al. 2019). To maintain its function, brain must be dynamically active over all its region (Striade et al. 1990). The possibility of higher beta brain waves signify that the cognitive process needed at the time of recording occurred more in the right brain. This is called a topdown information processing mechanism where internal information processing takes place using working memory to achieve certain goals (Benedek et al. 2011). Moreover, similar trend to previous research was achieved from the higher power spectral density in beta waves indicate that blue light exposure can increase brain wave response thus increasing voluntary motoric as well as cognitive response (Purawijaya et al. 2015). Monochromatic blue light results in an increase in cognitive function that is better than the placebo lamp which was polychromatic and this result proves that ipRGC functions with a very 
specific spectrum range, so that for applying the use of blue light to drivers, the blue light spectrum can be a major concern (Taillard et al. 2012). It is also associated with monochromatic and polychromatic light that have a melanopsin photosensitivity function (Revell et al. 2010). Since the right hemisphere of the frontal lobe showed higher power density than the left hemisphere, either in alpha or beta brain waves, this condition may reflect the inverse of cognitive activity (Bazanova \& Vernon 2014). When alpha waves are suppressed during driving, this condition may associate with attention and cognitive engagement (Mazaheri et al. 2014). Thus, monochromatic blue light can be applied in a car to help driver to improve alertness instead of drowsiness while driving at night as already proved in a study using the blue enriched white light in several workplaces (Viola et al. 2008).

\section{CONCLUSION}

Based on the research that has been done, it can be concluded that blue light exposure in 30-min duration and repeated in two consecutive night has significant effect of increasing both alpha and beta waves $(\mathrm{p}<0.01)$. Of the two types of treatment, namely monochromatic light (460 nm) and polycromatic placebo (450-549 nm), the monochromatic blue light causes a greater increase in the beta wave. Further research is needed to use a more accurate integration system, the number of narrators multiplied, more frequent data retrieval with a longer duration with different of light intensity.

\section{ACKNOWLEDGEMENTS}

This research was supported by P3MI (Program Penelitian, Pengabdian kepada Masyarakat dan Inovasi) ITB research funding year program 2018-2019.

\section{REFERENCES}

Bazanova, O.M. \& Vernon, D. 2014. Interpreting EEG alpha activity. Neuroscience and Biobehavioral Reviews 44: 94110.

Benedek, M., Bergner, S., Konen, T., Fink, A. \& Neubauer, A.C. 2011. EEG alpha synchronization is related to topdown processing in convergent and divergent thinking. Neuropsychologia 49(12): 3505-3511.

Blume, C., Garbazza, C. \& Spitschan, M. 2019. Effects of light on human circadian rhythms, sleep and mood. Somnologie 23(3): 147-156.

Boyce, P.R., Veitch, J.A., Newsham, G.R., Jones, C.C., Heerwagen, J., Myer, M. \& Hunter, C.M. 2006. Lighting Quality and Office Work: Two Field Simulation Experiments. Pacific Northwest National Laboratory, United States Department of Energy.

Cao, D. \& Barrionuevo, P.A. 2015. The importance of intrinsically photosensitive retinal ganglion cells and implication for lighting design. Journal of Solid State Lighting 2: 10-17.

Fitri, L.L., Chusnia, C. \& Suprijanto. 2018. Blue light exposure and visual distraction effect of the cognition brain waves of driver in car simulation at night. In IOP Conference Series: Earth and Environmental Science 197-012051. pp. 1-6.

Küller, R. 2002. The influence of light on circa rhythms in humans. Journal of Physiological Anthropology 21(2): 87-91.

Lim, S., Yeo, M. \& Yoon, G. 2019. Comparison between concentration and immersion based on EEG analysis. Sensors 19: $1-13$.

Lin, C.T., Wu, R.C., Liang, S.F., Chao, W.H., Chen, Y.J. \& Jung, T.P. 2005. EEG - Based drowsiness estimation for safety driving using independent component analysis. IEEE Transaction on Circuits and Systems-I: Regular Papers 52(12): 2726-2738.

Mazaheri, A., van Schouwenburg, M.R., Dimitrijevic, A., Denys, D., Cools, R. \& Jensen, O. 2014. Region-specific modulations in oscillatory alpha activity serve to facilitate processing in the visual and auditory modalities. NeuroImage 87 : 356-362.

Purawijaya, D.A., Fitri, L.L. \& Suprijanto. 2015. Evaluation of blue light exposure to $\beta$ brainwave on simulated night driving. In AIP Conference Proceedings for the 5th International Conference on Mathematics and Natural Sciences. pp. 1-3.

Revell, V.L., Barret, D.C.G., Schlangen, L.J.M. \& Skene, D.J. 2010. Predicting human nocturnal nonvisual responses to monochromatic and polychromatic light with a melanopsin photosensitivity function. Chronobiology International 27(9-10): 1762-1777.

Rumbayan, M., Abudureyimu, A. \& Nagasaka, K. 2012. Mapping of solar energy potential in Indonesia and geographical information system. Renewable and Sustainable Energy Reviews 16(2012): 1437-1449.

Sakai, H., Takahara, M., Honjo, N.F., Doi, S.I., Sadato, N. \& Uchiyama, Y. 2012. Regional frontal gray matter volume associated with executive function capacity as a risk factor for vehicle crashes in normal aging adults. PLOS ONE 7(9): e45920.

Santamaria, J. \& Chiappa, K.H. 1987. The EEG of drowsiness in normal adults. Journal of Clinical Neurophysiology 4(4): 327-382.

Subha, D.P., Joseph, P.K., Acharya, R. \& Lim, C.M. 2010. EEG signal analysis: A survey. Journal of Medical Systems 34: 195-212.

Taillard, J., Capelli, A., Sagaspe, P., Anund, A., Akerstedt, T. \& Phillip, P. 2012. In car nocturnal blue light exposure improves motorway driving: A randomized controlled trial. PLOS ONE 7(10): e46750.

Takahashi, N., Shimizu, S., Hirata, Y., Nara, H., Inoue, H., Hirai, N., Kikuchi, S., Watanabe, E. \& Kato, S. 2011. Basic study of analysis of human brain activities during car driving. In Human Interface, Part I, HCII, LCBS 6771. pp. 627-635.

Tosini, F., Ferguson, I. \& Tsubota, K. 2016. Effects of blue light on the circadian system and eye physiology. Molecular Vision 22: 61-72.

Treutlein, P. 2016. Photon qubit is made of two colors. Physics 9: 135.

Viola, A.U., James, L.M., Schlanger, L.J. \& Dijk, D.J. 2008. Blue-enriched white light in the workplace improves self-reported alertness, performance and sleep quality. 
Scandinavian Journal of Work, Environment \& Health 34(4): 297-306.

Zain-Ahmed, A., Sopian, K., Abidin, Z.Z. \& Othman, M.H.Y. 2002. The availability of daylight form tropical skies - A case study of Malaysia. Renewable Energy 25(1): 21-30.

Lulu Lusianti Fitri* \& Kinanti Prestiasani

School of Life Science and Technology

Institut Teknologi Bandung

Jalan Ganesha 10, Bandung 40312

Indonesia
Suprijanto

Engineering Physics Department

Faculty of Industrial Technology

Institut Teknologi Bandung

Jalan Ganesha 10, Bandung 40132

Indonesia

*Corresponding author; email: 1fitri@sith.itb.ac.id

Received: 26 January 2020

Accepted: 1 April 2020 